\title{
DIVERSITY AND MORPHOMETRY OF CHIROPTERAN FAUNA IN JAHANGIRNAGAR UNIVERSITY CAMPUS, SAVAR, DHAKA, BANGLADESH
}

\author{
Anik Saha*, Md Kamrul Hasan and Mohammed Mostafa Feeroz \\ Department of Zoology, Jahangirnagar University, Savar, Dhaka
}

\begin{abstract}
The study was conducted to know the diversity of Chiropterans as well as their status and morphometric measurements in Jahangirnagar University campus between July, 2014 and April, 2015. Eight species of bats from three families were identified where Common Pipistrelle (Pipistrellus pipistrellus) and Pouch Tomb Bat (Saccolaimus saccolaimus) were recorded for the first time in Bangladesh. A total of 31 bat individuals of 8 species were captured during 15 netting nights for morphological studies. Skull preparation was carried out for taking cranial measurements to identify the Pipistrelle species. No roosting colony of Pteropus gigantius was found in the study area but it visits the area only for foraging while the other species roost permanently. The old buildings in the study area provide suitable habitats for a significant number of insectivore bats. Indian Flying Fox (Pteropus gigantius) was the largest (mean head body length $23.33 \pm 1.86 \mathrm{~cm}$ ) and Least Pipistrelle (Pipistrellus tenuis) was the smallest (mean head body length $39.45 \pm 1.66$ $\mathrm{mm}$ ) species observed from the study area.
\end{abstract}

Key words: Chiroptera, diversity, morphometric measurements, cranial measurements, Jahangirnagar University.

\section{INTRODUCTION}

Chiropterans (bats) are the unique among all the mammals capable of flapping. They evolved during early Eocene period (Simmons and Geisler 1998) and consist about $25 \%$ of all the mammals found in the world today (Mickleburgh et al. 2002).A total of 128 species of bats have been recorded from South Asia (Srinivasuluet et al. 2010) where the actual number is skeptical in Bangladesh. Khan (2001) reported 31 species while Sarker and Sarker (2005) listed 29 species from Bangladesh. Srinivasulu and Srinivasulu (2005) reviewed the check list with 38 bat species and finally Khan (2015) revised the previous one concluding 33 species of bats in Bangladesh. Very few works have been carried out on bats and many species reported in the checklist on the basis on assumption. It is high time to think about bats as they are considered as key stone species responsible for pollination and seed dispersers (Cox et al. 1991, Fujita and Tuttle 1991, Rainey et al. 1995). The insectivore bats consume several hundreds of insects in one night and reduce the pests and other vectors of diseases (Adams 2003). Some tribal communities hunt Indian flying fox (Pteropus gigantius) for meat and few local people believe that the flesh of bats work against diseases.

* Corresponding author: mkhasan@ucdavis.edu

(C) 2015 Zoological Society of Bangladesh DOI: 10.3329/bjz.v43i2.27392 
The Jahangirnagar University Campus provides suitable habitat for bat species and a significant number of individuals have seen in the evening periods. Aziz et al. (2007) worked on three species on bats and Akther (2011) was gone through on morphometry with description of five species. The present study was focused on the status and diversity of bat species with their morphometry. The habitat preference was also considered for their future conservation.

\section{MATERIAL AND METHODS}

Study area: The study was carried out at Jahangirnagar University campus situated at the central region of Bangladesh and the geographical position was $30.16^{\circ} \mathrm{N}$ latitude and $90.26^{\circ} \mathrm{E}$ longitudes. The total area of the campus is covering 280hectares and it is placed on the distal patches of Sal (Shorea robusta) forest as well as grasslands (Hossain et al. 1995). The mixed vegetation consisted of wetlands, grasslands, cultivated lands, woodlands, bushes and human settlements as well as many old buildings providing habitats for bats. There are233 species of plants belonging to 168 genera from 62 families in the study area (Hossain et al. 1995). The diverged vegetation and habitat supported a significant number of wildlife species. Even new species were recorded in each and every year in the checklist. There are180 species of birds including 61 migrants are known to occur in the study area (Mohsanin and Khan 2009) and even this number is increasing day by day. The climatic conditions of the university campus significantly varied in different months of the year. During the study period, humidity was maximum in the August $(89.15 \%)$ and minimum in the March (48.96\%), whereas the highest temperature recorded in April $\left(31.17^{\circ} \mathrm{C}\right)$ and lowest found in December $\left(17.71^{\circ} \mathrm{C}\right)$ (Weather station, Jahangirnagar University).

Study period: The study was carried out for 10 months from the July, 2014 to April, 2015. As the bats were nocturnal flying mammals it was not possible to identify easily by direct observation. Capturing was essential to take necessary measurements in different parameters for proper identification.

Method: Mist nets were used to capture bats from the natural habitats such as fruit gardens, open fields, grasslands and old buildings. After removing from the mist net, the bats were kept in a cotton bag. The sexes were differentiated by the presence of external genital organs and reproductive stages (adult/ Juvenile) were determined on the basis of ossification of finger bones (Kunz, 1988). Skulls were also prepared to identify Pipistrelle species.

Morphometric measurements: Morphometric measurements were taken by using digital slide calipers (CD-6" CSX). The weight was taken by electric balance (EK600I). Data were taken on the following parameters (Fig. 1):

Head body (HB), Forearm (FA), Third metacarpal (3mt),First phalanx of third metacarpal (1ph3mt), Second Phalanx of third metacarpal (2ph3mt), Tibia length 
(TIB), Hind feet (HF), Tail length (TL), Ear length (EL), Tragus (T) and Weight (W).

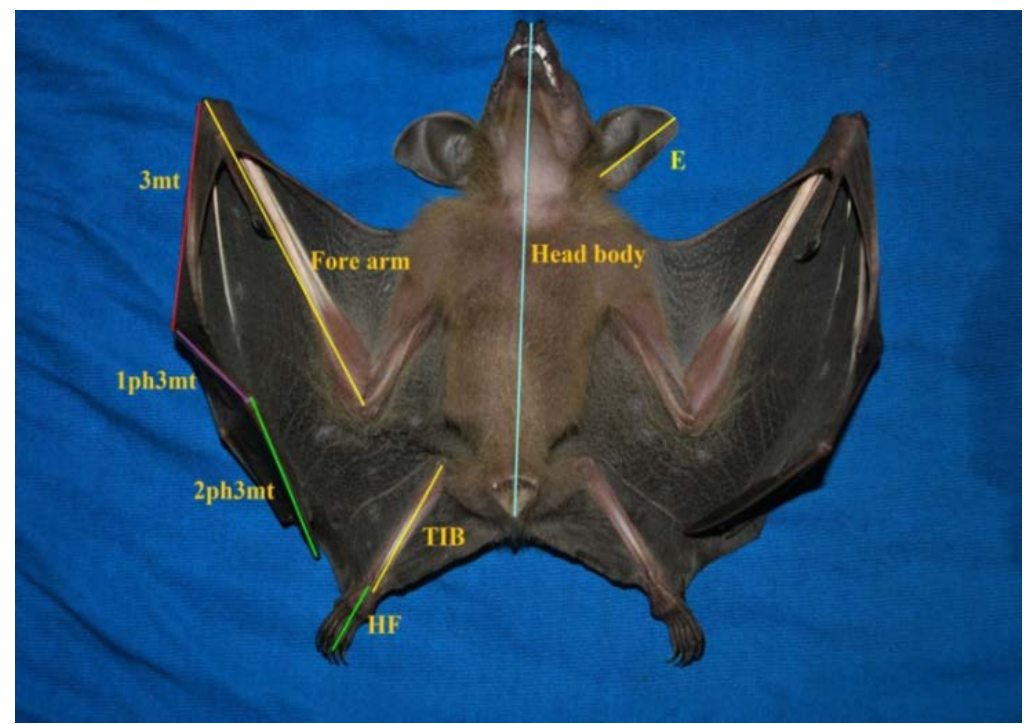

Fig. 1. Parameters used for morphometric measurements of a bat.

Cranial Measurements: Skull preparation was carried out for cranial measurements on following parameters.

The greatest length of skull (GTL), condylo-basal length (CBL), condylocanine length (CCL), breadth of braincase (BB), mandibular length (ML), maxillary tooth row $\left(\mathrm{C}-\mathrm{M}^{3}\right)$, mandibular tooth $\operatorname{row}\left(\mathrm{C}-\mathrm{M}_{3}\right)$, anterior palatal width $\left(\mathrm{C}^{1}-\mathrm{C}^{1}\right)$, and posterior palatal width $\left(\mathrm{M}^{3}-\mathrm{M}^{3}\right)$.

Identification: Identification of bats was carried out analyzing the morphometric measurements as well as some external key characters. The data were compared with Bates and Harrison (1997) and Srinivasulu et al. (2010). In case of Pipistrelle species, cranial measurements and dental formation were used along with the external measurements for confirmation.

\section{RESULTS AND DISCUSSION}

A total of 31 individual of bats were captured during the study period netting out for 15 nights and measured. Eight species of bats under three families (Pteropodidae, Verspertilionidae and Emballonuridae) were recorded from the study area. These were Indian Flying Fox (Pteropus gigantius), Greater Shortnosed Fruit bat (Cynopterus sphinx), Asiatic Greater Yellow hose bat (Scotophilus heathi), Asiatic Lesser yellow house bat (Scotophilus kuhlii), Coromandel Pipistrelle (Pipistrellus coromandra), Least Pipistrelle (Pipistrellus tenuis), Common Pipistrelle (Pipistrellus pipistrellus) and Pouched Tomb bat (Saccolaimus saccolaimus) (Table 1). 
Table 1. The list of bats captured and identified during study period

\begin{tabular}{|c|c|c|c|c|}
\hline Common name & Scientific name & Suborder & Family & Location \\
\hline Indian Flying Fox & Pteropus gigantius & Megachiroptera & Pteropodidae & $\begin{array}{l}\text { Behind the } \\
\text { biological } \\
\text { faculty }\end{array}$ \\
\hline $\begin{array}{l}\text { Greater Short- } \\
\text { nosed Fruit bat }\end{array}$ & Cynopterus sphinx & Megachiroptera & Pteropodidae & $\begin{array}{l}\text { In front of New } \\
\text { arts building }\end{array}$ \\
\hline $\begin{array}{l}\text { Asiatic Greater } \\
\text { Yellow House bat }\end{array}$ & Scotophilus heathii & Microchiroptera & Vespertilionidae & B.B.H. \\
\hline $\begin{array}{l}\text { Asiatic Lesser } \\
\text { Yellow House bat }\end{array}$ & Scotophilus kuhlii & Microchiroptera & Vespertilionidae & S.S.B.H. \\
\hline $\begin{array}{l}\text { Coromandel } \\
\text { Pipistrelle }\end{array}$ & Pipistrellus coromandra & Microchiroptera & Vespertilionidae & M.M.H. \\
\hline Least Pipistrelle & Pipistrellus tenuis & Microchiroptera & Vespertilionidae & B.B.H. \\
\hline $\begin{array}{l}\text { Common } \\
\text { pipistrelle }\end{array}$ & Pipistrellus pipistrellus & Microchiroptera & Vepsertilionidae & M.V.H. \\
\hline Pouch Tomb bat & Saccolaimus saccolaimus & Microchiroptera & Emballonuridae & S.S.B.H. \\
\hline
\end{tabular}

B.B.H.: Bangabandhu hall; S.S.B.H.: Saheed Salam Barkat hall; M.M.H: Mir Mosharorof hall; M.V.H.: MaulanaVashani hall

Morphometry: Pteropus gigantius was the largest bat species while Pipistrellus tenuis was the smallest one in the study area. The detail morphometry of these species are as follows.

\section{Indian Flying Fox (Pteropus gigantuis)}

This was the largest bat recorded from the study site containing long snout and two well-developed nostril. The ears were movable, long, pointed and black in colouration. Eyes were large and functional while the tail was absent. The pelage of the back was black, lightly streaked grey; mantle pale yellow brown; head brown and under parts buffy brown (Fig. 2a). The average head body length was $23.33 \pm 1.86 \mathrm{~cm}(\mathrm{n}=3)$ where the range varied from $21.40-25.10 \mathrm{~cm}$ (Table 3). The fore arm was $15.6 \pm 1.01(14.5-16.5) \mathrm{cm}$; hind feet, $4.6 \pm 0.17$ (4.54.8) $\mathrm{cm}$; tibia, $6.97 \pm 0.55(6.40-7.50) \mathrm{cm}$; ear, $4.13 \pm 0.15(4-4.3) \mathrm{cm} ; 3 \mathrm{mt}$, $10.9 \pm 1.15$ (9.7-12) $\mathrm{cm} ; 1 \mathrm{ph} 3 \mathrm{mt}, 7.16 \pm 1.21 \quad(5.8-8.1) \mathrm{cm}$ and $2 \mathrm{ph} 3 \mathrm{mt}$ was $9.67 \pm 1.04(8.5-10.5) \mathrm{cm}$ respectively (Table 3$)$. 

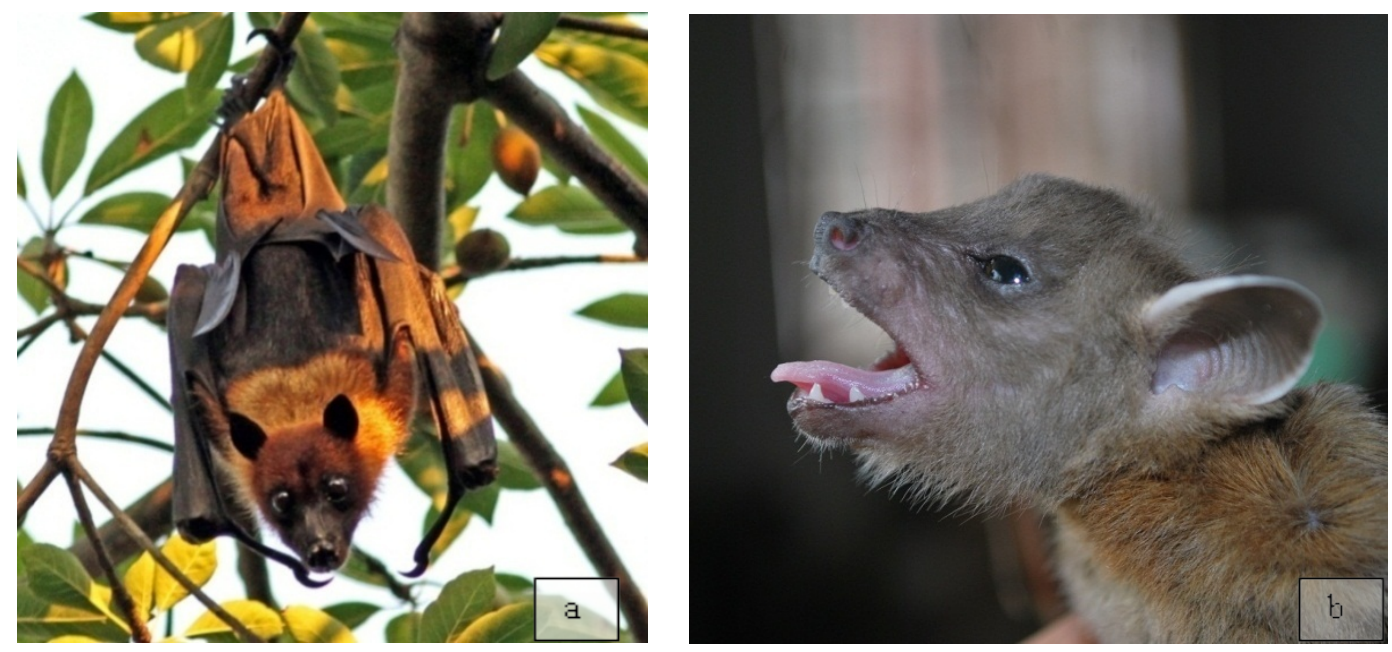

Fig. 2. (a) Pteropus gigantius (b) Cynopterus sphinx

\section{Greater Short-nosed Fruit bat (Cynopterus sphinx)}

The muzzle was comparatively short, broad and the pelage of upper parts was brown to grey brown and under parts comparatively paler (Fig. 2b). The wing membrane was dark brown throughout where the inter-femoral membrane hairy above and below. The anterior and posterior edges of the ears contained pale white border (Fig. 2b).The average head body length was $92.57 \pm 2.67 \mathrm{~mm}(\mathrm{n}=4)$ and the range varied from $88.29-94.10 \mathrm{~mm}$ (Table 3). The forearm was $69.13 \pm 1.50(67.79-69.23) \mathrm{mm}$; hind feet, $14.91 \pm 1.35(13.51-16.76) \mathrm{mm}$; tibia, $25.35 \pm 0.62(24.83-26.23) \mathrm{mm}$; ear, $19.3 \pm 0.76(18.56-20.37) \mathrm{mm} ; 3 \mathrm{mt}$, $43.08 \pm 1.57$ (41.11-44.40) mm; $1 \mathrm{ph} 3 \mathrm{mt}, 22.36 \pm 0.63$ (21.86-23.28) mm; $2 \mathrm{ph} 3 \mathrm{mt}$ $24.58 \pm 0.66$ (24.06-25.29) $\mathrm{mm}$; tail, $12.30 \pm 0.83$ (11.36-13.1) $\mathrm{mm}$ and weight was 47.07 $\pm 2.92(44.47-51.01)$ gm respectively (Table 3).

\section{Asiatic Greater Yellow House bat (Scotophilus heathi)}

One male individual was captured and measured for the study. The pelage of the upper part was orange to reddish brown and the hair with yellow bases (Fig. 3a). The furs were looking smooth and shiny where the lower part was pale yellow to brown in appearance. The nostrils were simple, rounded and slightly outward. Ears and inter-femoral membranes were brown in coloration and without hairs (Fig. 3a). The antitragus contained a distinct notch, by which it was separated from the posterior margin of the pinnae. The tragus was long, narrow and bent forward where the hind feet were half of the length of tibia. This was a robust bat with head-body measured up to $87.99 \mathrm{~mm}$ where the forearm was $58.49 \mathrm{~mm}$ long (Table 3 ). The ear was moderate in size and measured upto $13.82 \mathrm{~mm}$. The hind feet, tibia length and first phalanx of third meta-carpal were $10.11 \mathrm{~mm}, 21.27 \mathrm{~mm}$ and $19.16 \mathrm{~mm}$ respectively (Table 3). The tail length was $52.03 \mathrm{~mm}$ whereas the tragus measured up to $7.1 \mathrm{~mm}$. 

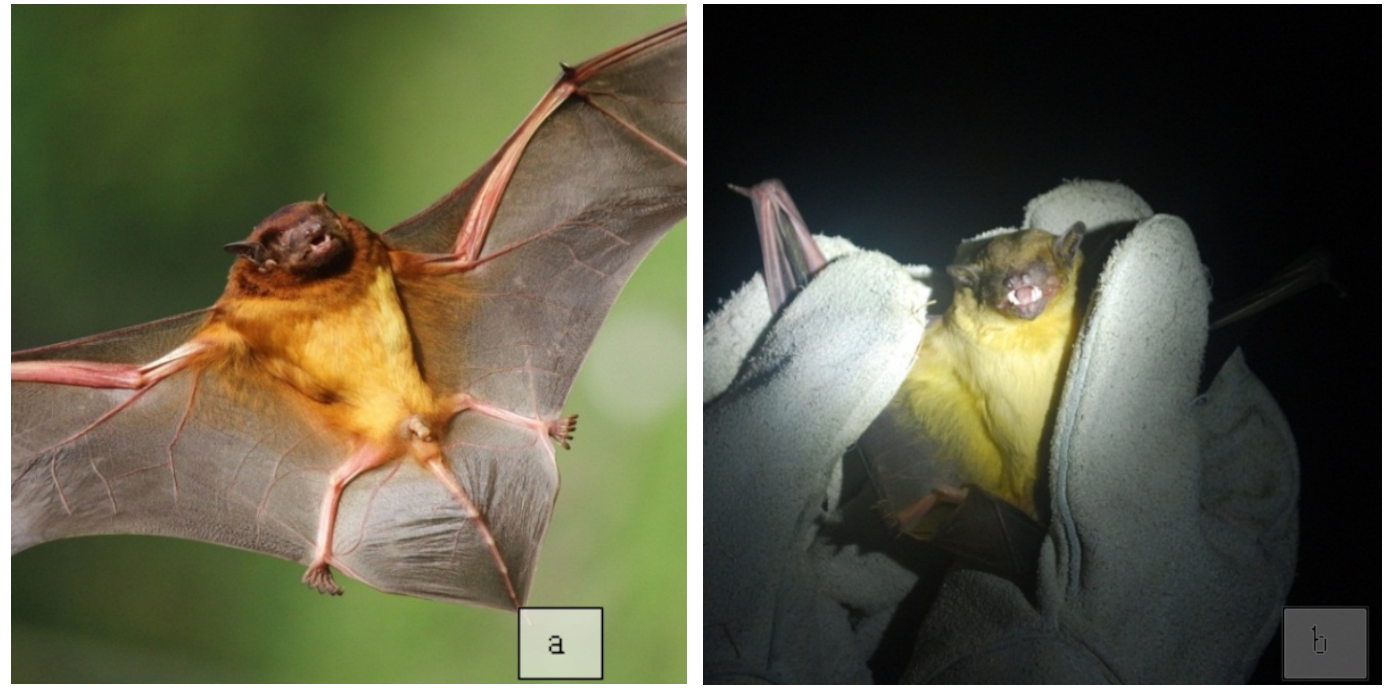

Fig. 3. (a) Scotophilus heathi (b) Scotophilus kuhlii

\section{Asiatic Lesser Yellow House bat (Scotophilus kuhlii)}

The pelage of the upper part was brown while under part was paler yellow brown (Fig. 3b). The furs and hairs were comparatively short as well as smooth. Ears were moderate in size containing long narrow tragus that bent forward. This was a medium sized bat almost similar in external features with the $S$. heathi but differ in sizes. The average head body length was $81.00 \pm 3.676 \mathrm{~mm}$ $(\mathrm{n}=4)$ with the range varied from $77.1-84.83 \mathrm{~mm}$. The fore arm was $56.46 \pm 1.37 \mathrm{~mm}$ and the range was found from $55.26-57.95 \mathrm{~mm}$ (Table 3). The hind feet was $10.24 \pm 1.05(9.32-11.38) \mathrm{mm}$; tibia, $22.00 \pm 1.83(20.47-24.03) \mathrm{mm}$; ear, $12.05 \pm 0.71(11.26-12.63) \mathrm{mm} ; 3 \mathrm{mt}, 53.08 \pm 2.39(50.78-55.56) \mathrm{mm} ; 1 \mathrm{ph} 3 \mathrm{mt}$, $15.30 \pm 3.06$ (12.27-18.4) mm; 2ph3mt, 23.58 1.38 (22.45-25.12)mm; tail, $51.08 \pm 3.89(47.23-55.01) \mathrm{mm}$ and tragus was $6.36 \pm 0.67(5.68-7.01) \mathrm{mm}$ (Table $3)$.

\section{Coromandel Pipistrelle (Pipistrellus coromandra)}

This was a small Pipistrelle. Its pelage of upper parts was generally dark brown and the bases of the fur and hairs were quite darker (Fig. 4a). The ear was brown in appearance and essentially naked with a fold in middle edge (Fig. 4a). The tragus was short, blunt and rounded. The wing membrane was brown and the bases of wing membrane contained some hairs. The head body length varied from $39.97-41.43 \mathrm{~mm}$ and the mean was $40.7 \pm 1.03 \mathrm{~mm}(\mathrm{n}=2)$ (Table 3). The average length of forearm was $28.725 \pm 1.05 \mathrm{~mm}$ where the range was to 27.98-29.47mm (Table 3). The length of hind feet was 6.54 \pm 0.11 (6.46-6.61) $\mathrm{mm}$; tibia, $11.2 \pm 0.24$ (11.03-11.37) $\mathrm{mm}$; ear, 9.23 \pm 1.27 (8.36-10.15) $\mathrm{mm}$; $1 \mathrm{ph} 3 \mathrm{mt}, 10.69 \pm 0.32$ (10.47-10.92) mm; 2ph3mt, $13.99 \pm 0.37$ (13.73-14.26)mm; tail, 28.675 $\pm 0.38(28.41-28.94) \mathrm{mm}$; tragus, $4.94 \pm 0.03(4.96-4.92) \mathrm{mm}$ and the 
weight was $4.12 \pm 0.08(4.06-4.18) \mathrm{gm}$. (Table 3). The braincase was flatten and straight rostral profile. The greatest length of skull(GTL), condro-basal length $(\mathrm{CBL})$, condro-canine length (CCL) and brain case (BB) were $11.82 \mathrm{~mm}$, $11.09 \mathrm{~mm}, 10.34 \mathrm{~mm}$ and $6.16 \mathrm{~mm}$ respectively (Table 2). The maxillary tooth row $\left(\mathrm{C}-\mathrm{M}^{3}\right)$, mandibular tooth row $\left(\mathrm{C}-\mathrm{M}_{3}\right)$, anterior palatal width $\left(\mathrm{C}^{1}-\mathrm{C}^{1}\right)$ and posterior palatal width $\left(\mathrm{M}^{3}-\mathrm{M}^{3}\right)$ were measured up to $3.02 \mathrm{~mm}, 3.53 \mathrm{~mm}, 3.86 \mathrm{~mm}$ and $5.24 \mathrm{~mm}$ respectively (Table 2 ). The mandibular length was $8.10 \mathrm{~mm}$. The upper canine contained distinct secondary cusp with singular cusp.

\section{Least Pipistrelle (Pipistrellus tenuis)}

The pelage of the upper part was mid brown whereas the under part was slightly paler (Fig. 4b). The back of the head and neck were deep clove brown in appearance. The ears were short, somewhat straighten and oval in shape (Fig. 4b). The posterior edge of the ear contained week fold. The tragus was short, blunt and angled forwards. The wing membrane was smooth and hairless (Fig. 4b). These were the smallest bat where head body length was ranged from 36.9$41.23 \mathrm{~mm}$ with the mean $39.45 \pm 1.66 \mathrm{~mm}(\mathrm{n}=7)$ (Table 3$)$. The length of forearm was $27.81 \pm 1.06(26.4-28.59) \mathrm{mm}$; hind feet, $5.8 \pm 0.48(5-6.5) \mathrm{mm}$; tibia, $10.38 \pm 0.36$ (9.92-10.85) mm; ear, $7.89 \pm 1.08$ (6.84-9.91) mm; 3mt, 25.31 \pm 1.97 (22.23-27.75) mm; $1 \mathrm{ph} 3 \mathrm{mt}, 9.79 \pm 1.32$ (7.7-11.24) mm; $2 \mathrm{ph} 3 \mathrm{mt}, 13.19 \pm 1.03$ (11.69-14.47) mm; tail, $26.20 \pm 1.37(24.24-28.48) \mathrm{mm}$; tragus, $3.73 \pm 0.32$ (3.464.22) $\mathrm{mm}$ and the weight was $3.21 \pm 0.22(2.95-3.38) \mathrm{gm}$. (Table 3$)$. The skull was flattening and the mandibular length measured up to $7.52 \mathrm{~mm}$ whereas the maxillary tooth row and mandibular tooth row were $3.22 \mathrm{~mm}$ and $4.10 \mathrm{~mm}$ respectively (Table 2). The anterior palatal width was $3.82 \mathrm{~mm}$ and the posterior palatal width was $4.84 \mathrm{~mm}$ (Table 2). The upper canine contained distinct posterior secondary cusp.
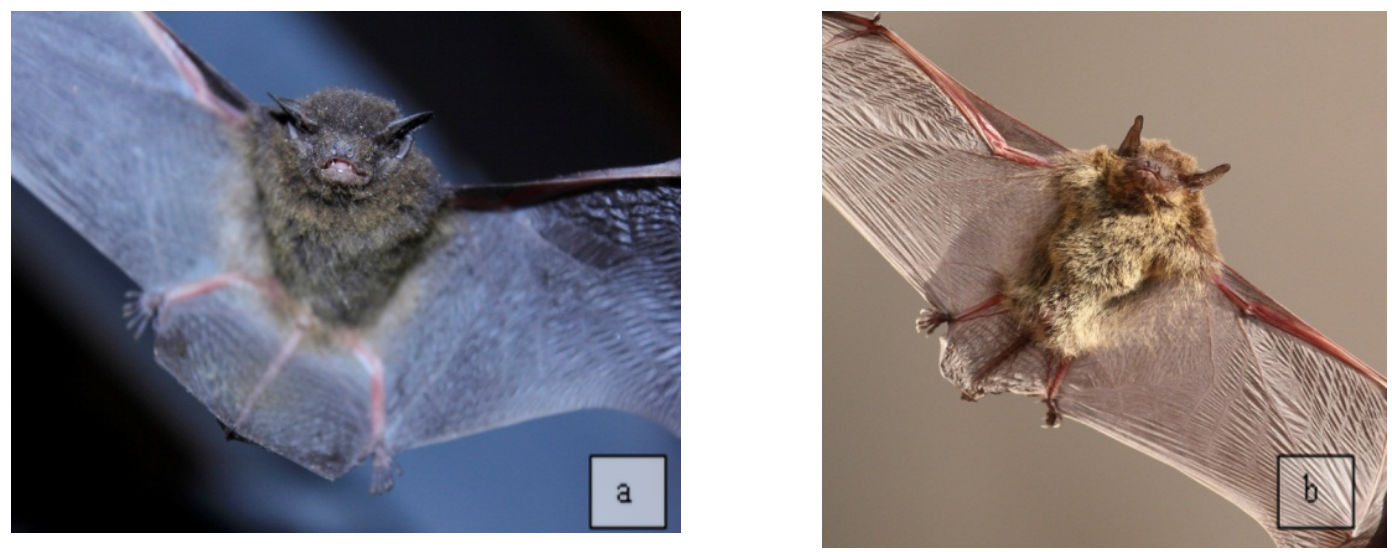

Fig. 4. (a) Pipistrellus coromandra (b) Pipistrellus tenuis 


\section{Common Pipistrelle (Pipistrellus pipistrellus)}

This was a small bat which ear was short and broad; the anterior border was convex where the posterior border concaved (Fig. 5a). The tragus was comparatively straight, banana shaped and rounded at the posterior edge. Its height reached the half of the height of the pinnae. The fur was dense, silky and uniform buffy brown to orange above the head and back (Fig. 5a). The muzzle and ears were quite darker in appearance. The head-body length was $40.76 \pm 0.89 \mathrm{~mm}$ and the range varied from $39.41-41.72 \mathrm{~mm}$ (Table 3). The average length of forearm was $26.82 \pm 0.32 \mathrm{~mm}(\mathrm{n}=5)($ range $26.56-27.35 \mathrm{~mm})$; hind feet, $5.34 \pm 0.21$ (5.09-5.58)mm; tibia, $9.90 \pm 0.30$ (9.56-10.35) $\mathrm{mm}$; ear, $8.07 \pm 0.45$ (7.37-8.46)mm; 3mt, 25.87 $\pm 0.41(25.27-26.32) \mathrm{mm} ; 1 \mathrm{ph} 3 \mathrm{mt}, 10.29 \pm 0.28(10.01-$ $10.71) \mathrm{mm}$; tail, $26.81 \pm 1.05(25.92-28.52) \mathrm{mm}$; tragus, $3.55 \pm 0.32(3.21-3.92) \mathrm{mm}$ and the weight was $3.52 \pm 0.26(3.04-3.83) \mathrm{gm}$. respectively (Table 3 ). The brain case was robust; dome shaped and measured up to $6.25 \mathrm{~mm}$. The greatest length (GTL) of the skull was $12.41 \mathrm{~mm}$ where the condro-basal (CBL) and condrocanine (CCL) length were $11.38 \mathrm{~mm}$ and $11.17 \mathrm{~mm}$ respectively (Table 2). The anterior palatal width $\left(\mathrm{C}^{1}-\mathrm{C}^{1}\right)$ was $3.63 \mathrm{~mm}$ where the posterior palatal $\left(\left(\mathrm{M}^{3}-\mathrm{M}^{3}\right)\right.$ width was $5.08 \mathrm{~mm}$ (Table 2). The length of the mandible was $8.09 \mathrm{~mm}$. The length of maxillary tooth row $\left(\mathrm{C}-\mathrm{M}^{3}\right)$ and mandibular tooth row $\left(\mathrm{C}-\mathrm{M}_{3}\right)$ were $3.88 \mathrm{~mm}$ and $4.06 \mathrm{~mm}$ (Table 2). The upper canine was robust containing well defined angle at the posterior cutting edge sub equal to the height of the shaft.

Table 2. Cranial measurements of Pipistrelle species

\begin{tabular}{llll}
\hline Attributes (mm) & P. pipistrellus & P. coromandra & P. tenuis \\
\hline GTL & 12.41 & 11.82 & NT \\
CBL & 11.38 & 11.09 & NT \\
CCL & 11.17 & 10.34 & NT \\
BB & 6.25 & 6.16 & NT \\
$\mathrm{C}^{-}{ }^{3}$ & 3.88 & 3.02 & 3.22 \\
$\mathrm{C}^{-}{ }_{3}$ & 4.06 & 3.53 & 4.10 \\
$\mathrm{C}^{1}-\mathrm{C}^{1}$ & 3.63 & 3.86 & 3.82 \\
$\mathrm{M}^{3}-\mathrm{M}^{3}$ & 5.08 & 5.24 & 4.84 \\
$\mathrm{M}$ & 8.09 & 8.10 & 7.52 \\
\hline
\end{tabular}

GTL: The greatest length of skull, CBL: condyle-basal length, CCL: Condyle-canine length, BB: Breadth of braincase, ML: Mandibular length, $\mathrm{C}^{-\mathrm{M}^{3}}$ : Maxillary tooth row, $\mathrm{C}-\mathrm{M}_{3}$ : Mandibular tooth row, $\mathrm{M}^{3}-\mathrm{M}^{3}$ : Posterior palatal width and: $\mathrm{C}^{1}-\mathrm{C}^{1}$ : Anterior palatal width, NT: Not taken.

\section{Pouched Tomb Bat (Saccolaimus saccolaimus)}

Five individuals were captured from the student dormitory. The pelage was dark brown to black above the dorsal portion containing the irregular white 
ISSN: 0304-9027 (Print)

2408-8455 (Online)

Table 3. Morphometric measurements of bats from Jahangirnagar University Campus

\begin{tabular}{|c|c|c|c|c|c|c|c|c|c|c|c|c|c|c|c|}
\hline \multirow[t]{2}{*}{ Attributes } & \multicolumn{2}{|c|}{$\begin{array}{l}\text { P. gigantius } \\
\qquad \begin{array}{l}\text { (cm) } \\
\mathbf{N}=3\end{array}\end{array}$} & \multicolumn{2}{|c|}{$\begin{array}{c}\text { C. sphinx } \\
\begin{array}{c}(\mathrm{mm}) \\
\mathrm{N}=4\end{array}\end{array}$} & \multirow{2}{*}{$\begin{array}{c}\begin{array}{c}\text { S. heathii } \\
(\mathrm{mm}) \\
\mathrm{N}=1\end{array} \\
\text { Mean }\end{array}$} & \multicolumn{2}{|c|}{$\begin{array}{c}\text { S. kuhlii } \\
\text { (mm) } \\
\mathrm{N}=4\end{array}$} & \multicolumn{2}{|c|}{$\begin{array}{c}\text { P. coromandra } \\
\begin{array}{c}(\mathrm{mm}) \\
\mathrm{N}=2\end{array}\end{array}$} & \multicolumn{2}{|c|}{$\begin{array}{c}\begin{array}{c}\text { P. tenius } \\
(\mathrm{mm}) \\
\mathrm{N}=7\end{array}\end{array}$} & \multicolumn{2}{|c|}{$\begin{array}{c}\text { P. pipistrellus } \\
\begin{array}{c}(\mathrm{mm}) \\
\mathrm{N}=5\end{array}\end{array}$} & \multicolumn{2}{|c|}{$\begin{array}{c}\text { S. saccolaimus } \\
\begin{array}{c}(\mathrm{mm}) \\
\mathrm{N}=5\end{array}\end{array}$} \\
\hline & Range & Mean & Range & Mean & & Range & Mean & Range & Mean & Range & Mean & Range & Mean & Range & Mean \\
\hline HB & $21.4-25.1$ & $23.33 \pm 1.86$ & 88.29-94.1 & $92.57 \pm 2.67$ & 87.99 & $77.1-84.83$ & $81.0 \pm 3.67$ & $39.97-41.43$ & $40.7 \pm 1.03$ & $36.9-41.23$ & $39.45 \pm 1.66$ & $39.41-41.72$ & $40.762 \pm 0.89$ & $87.55-95.99$ & $90.69 \pm 3.72$ \\
\hline FA & $14.5-16.5$ & $15.6 \pm 1.01$ & $67.89-69.23$ & $69.13 \pm 1.50$ & 58.49 & $\begin{array}{l}55.26- \\
57.95\end{array}$ & $56.46 \pm 1.37$ & $27.98-29.47$ & $28.725 \pm 1.05$ & $26.4-28.59$ & $27.81 \pm 1.06$ & $26.56-27.35$ & $26.828 \pm 0.32$ & $68.16-72.02$ & $70.8 \pm 1.82$ \\
\hline $\mathrm{HF}$ & $4.5-4.8$ & $4.6 \pm 0.17$ & $13.51-16.76$ & $14.91 \pm 1.35$ & 10.11 & $9.32-11.38$ & $10.24 \pm 1.05$ & $6.46-6.61$ & $6.54 \pm 0.11$ & $5-6.5$ & $5.8 \pm 0.48$ & $5.09-5.58$ & $5.342 \pm 0.21$ & $12.03-15.16$ & $13.79 \pm 1.31$ \\
\hline ТІB & $6.4-7.5$ & $6.97 \pm 0.55$ & $24.83-26.23$ & $25.35 \pm 0.62$ & 21.27 & $\begin{array}{l}20.47- \\
24.03\end{array}$ & $22.0 \pm 1.83$ & $11.03-11.37$ & $11.2 \pm 0.24$ & $9.92-10.85$ & $10.38 \pm 0.36$ & 9.56-10.35 & $9.90 \pm 0.30$ & $25.41-29.38$ & $27.4 \pm 1.73$ \\
\hline EL & $4-4.3$ & $4.13 \pm 0.15$ & $18.56-20.37$ & $19.3 \pm 0.76$ & 13.82 & $\begin{array}{l}11.26- \\
12.63\end{array}$ & $12.0 \pm 0.71$ & $8.36-10.15$ & $9.23 \pm 1.27$ & 6.84-9.91 & $7.89 \pm 1.08$ & $7.37-8.46$ & $8.07 \pm 0.45$ & $12.73-14.49$ & $13.83 \pm 0.81$ \\
\hline $3 \mathrm{mt}$ & $9.7-12$ & $10.9 \pm 1.15$ & $41.11-44.4$ & $43.08 \pm 1.47$ & 58.01 & $\begin{array}{l}50.78- \\
55.56\end{array}$ & $53.08 \pm 2.39$ & $25.34-25.73$ & $25.535 \pm 0.27$ & $22.23-27.75$ & $25.31 \pm 1.97$ & $25.27-26.32$ & $25.87 \pm 0.41$ & $66.37-72.05$ & $69.14 \pm 2.37$ \\
\hline $1 \mathrm{ph} 3 \mathrm{mt}$ & $5.8-8.1$ & $7.16 \pm 1.21$ & $21.86-23.28$ & $22.36 \pm 0.63$ & 19.16 & $12.27-18.4$ & $15.30 \pm 3.06$ & $10.47-10.92$ & $10.695 \pm 0.32$ & 7.7-11.24 & $9.79 \pm 1.32$ & $10.01-10.71$ & $10.29 \pm 0.28$ & 27.4-28.92 & $28.22 \pm 0.69$ \\
\hline $2 \mathrm{ph} 3 \mathrm{mt}$ & $8.5-10.5$ & $9.67 \pm 1.04$ & $24.06-25.29$ & $24.58 \pm 0.66$ & NT & $\begin{array}{l}22.45- \\
25.12\end{array}$ & $23.58 \pm 1.38$ & $13.73-14.26$ & $13.995 \pm 0.37$ & $11.69-14.47$ & $13.19 \pm 1.03$ & NT & NT & 27.46-29.11 & $\begin{array}{l}28.03 \\
\pm 0.75\end{array}$ \\
\hline $\mathrm{TL}$ & A & A & $11.36-13.1$ & $12.30 \pm 0.83$ & 52.03 & $\begin{array}{l}47.23- \\
55.01\end{array}$ & $51.08 \pm 3.89$ & 28.41-28.94 & $28.675 \pm 0.38$ & $24.24-28.48$ & $26.20 \pm 1.37$ & $25.92-28.52$ & $26.81 \pm 1.05$ & $26.51-31.31$ & $28.17 \pm 2.18$ \\
\hline Tragus & A & A & NT & NT & 7.1 & 5.68-7.01 & $6.36 \pm 0.67$ & $4.96-4.92$ & $4.94 \pm 0.03$ & $3.46-4.22$ & $3.73 \pm 0.32$ & 3.21-3.92 & $3.55 \pm 0.32$ & $5.07-5.63$ & $5.31 \pm 0.25$ \\
\hline Weight & NT & NT & $44.47-51.01$ & $47.07 \pm 2.92$ & NT & NT & NT & $4.06-4.18$ & $4.12 \pm 0.08$ & $2.95-3.38$ & $3.21 \pm 0.22$ & 3.04-3.83 & $3.52 \pm 0.26$ & $41.46-47.5$ & $43.41 \pm 2.83$ \\
\hline
\end{tabular}

HB: Head body, FA: Fore arm, HF: Hind feet, TIB: Length of tibia, E: Ear length, 1ph3mt: First phalanx of the $3^{\text {rd }}$

metacarpal, 2ph3mt: Second phalanx of the $3^{\text {rd }}$ metacarpal, 3mt: Third metacarpal, T: Tail length, NT: Not taken. 

patches (Fig. 5b). The radio metacarpal pouch was absent on the wing and a deep narrow groove found under the lower lip. The inter-femoral membranes and the legs were hairless (Fig. 5b). Eyes were comparatively small and quite black in appearance. The head body length was $90.69 \pm 3.72 \mathrm{~mm}$ and the range was $87.55-95.99 \mathrm{~mm}$ (Table 3$)$. The forearm was $70.80 \pm 1.82(68.16-72.02) \mathrm{mm}$; hind feet, 13.79 $\pm 1.31(12.03-15.16) \mathrm{mm}$; tibia, $27.4 \pm 1.73(25.41-29.38) \mathrm{mm}$; ear, $13.83 \pm 0.81 \quad(12.73-14.49) \mathrm{mm} ; 3 \mathrm{mt}, 69.14 \pm 2.37 \quad(66.37-72.05) \mathrm{mm} ; 1 \mathrm{ph} 3 \mathrm{mt}$, $28.22 \pm 0.69$ (27.4-28.92)mm; 2ph3mt, 28.03 $\pm 0.75 \quad(27.46-29.11) \mathrm{mm} ; \quad$ tail, $28.17 \pm 2.18(26.51-31.31) \mathrm{mm}$; tragus, $5.31 \pm 0.25(5.07-5.63) \mathrm{mm}$ and the weight was $43.41 \pm 2.83$ (41.46-47.5) gm. (Table 3).
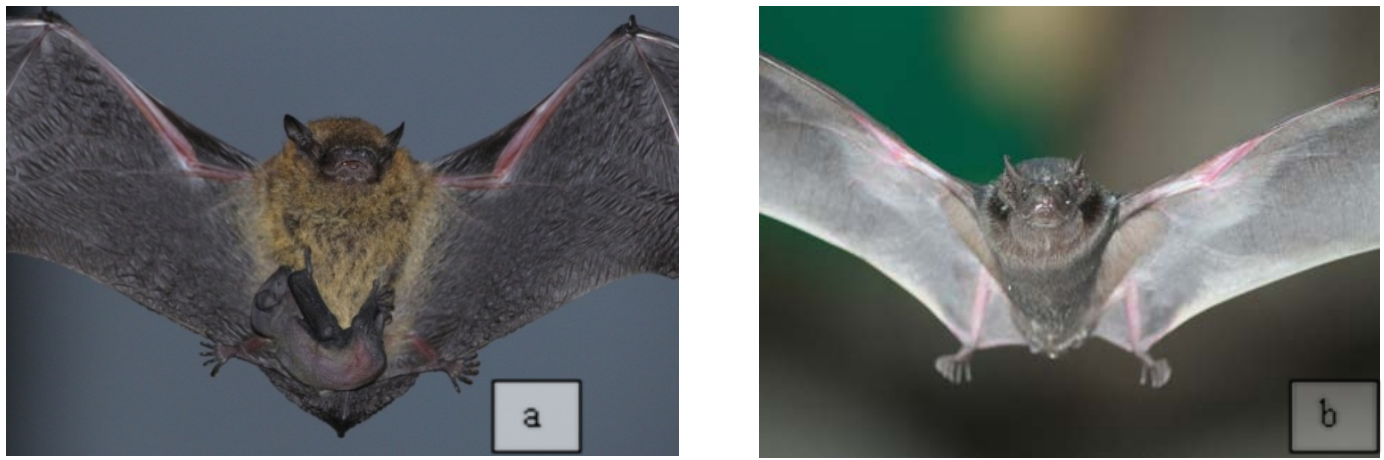

Fig. 5. (a) Pipistrellus pipistrellus (b) Saccolaimus saccolaimus
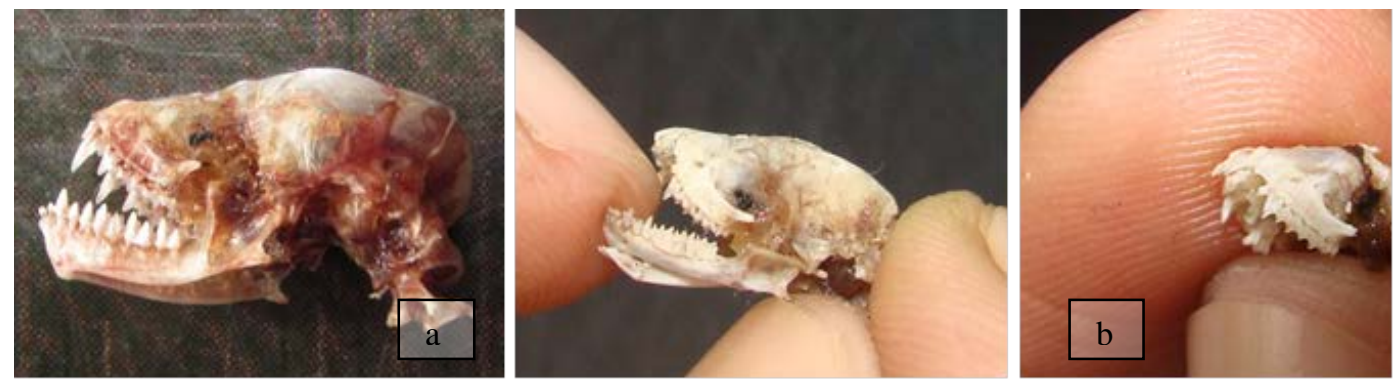

Fig. 6. Skulls of Pipistrelle species

(a) Pipistrellus pipistrellus (b) Pipistrellus coromandra (c) Pipistrellus tenuis

It was assumed that five species of bats are found in the Jahangirnagar University campus (Akther 2011). During the study period, eight species of bats were recorded from this study area. Among them Common Pipistrelle $(P$. pipistrellus) and Pouch Tomb bat (S. saccolaimus) were recorded for the first time in Bangladesh. The bat individuals were identified by morphometric measurements and some external features. Though the morphometric measurements were greatly overlapping in Pipistrelle species, skull preparation was carried out for taking cranial measurements to identify them. P. gigantius was a very common species in the study area though there was no roosting 
colony observed. The larger head body $(23.33 \pm 1.86 \mathrm{~cm})$, forearm $(15.6 \pm 1.01 \mathrm{~cm})$, ear $(4.13 \pm 0.15 \mathrm{~cm})$ and other measurements ensured the confirmation of $P$. gigantius (Table 3). C. sphinx was differentiated from other fruit bats on the presence of pale white border on the edges of the ear and the ear lengths (greater than $18 \mathrm{~mm}$ in this species) (Bates and Harrison 1997). The forearm length of $S$. heathi was measured $58.49 \mathrm{~mm}$ which was greater than $55 \mathrm{~mm}$ was a key component to identify from S. kuhlii (Francis 2008). Though the forearm length of $S$. kuhlii was found $56.46 \mathrm{~mm}$ but it was very nearer to $55 \mathrm{~mm}$. Again the head body length and other measurements of $S$. heathii were greater than $S$. kuhlii (Table 3). The brain case (BB) of P. coromandra and P. tenuis were flattening and comparatively straight whereas domed shaped and robust brain case was found in P. pipistrellus (Fig. 6). The condro-canine $(\mathrm{CCL}=11.17 \mathrm{~mm})$ and condro-basal $(\mathrm{CBL}=11.38 \mathrm{~mm})$ length of $P$. pipistrellus were greater than $P$. coromandra. But the anterior palatal $\left(\mathrm{C}^{1}-\mathrm{C}^{1}=3.86 \mathrm{~mm}\right)$ width as well as posterior palatal width $\left(\mathrm{M}^{3}-\right.$ $\mathrm{M}^{3}=5.24 \mathrm{~mm}$ ) of $P$. coromandra was greater than $P$. pipistrellus and $P$. tenuis. The upper canine of $P$. coromandra and $P$. tenuis contained distinct secondary cusps where $P$. pipistrellus had well defined angle on the posterior cutting edge (Fig. 6). Even the tragus shapes were different among the three Pipistrelle species. The deep narrow groove under the chin and irregular white patches on the dorsal portion were given the strong confirmation of $S$. saccolaimus (Fig. 5b). All the external measurements of $S$. saccolaimus were fallen in the range given by Bates and Harrison (1997).

Acknowledgements: We are thankful to the authority and all the staffs of Wildlife Rescue Centre (WRC) of Jahangirnagar University for their kind help and logistics during survey periods. Special thanks to Hamlet Barman, Showaib Hossain and Tawfiquar Rahman for helping us during capturing of bats and morphometric data collection.

\section{LITERATURE CITED}

AZIZ, M.A., REZA, A.H.M.A., HASAN, M.K., TONCHANGYA, P.K., SARKER, A., ATIQUZZAMAN, K.M., DUTTA, S., MAKAYCHING and RAHMAN, K.M.Z. 2007. Some notes on three species of bats of Jahangirnagar University. Zoos' Print Journal. 22(6): 2729-2731.

AKTER, S., RAHMAN, F. and AZIZ, M.A. 2013.Investigating the least known small mammals of Jahangirnagar University campus, Bangladesh. Small Mammal Mail Bi-Annual Newsletter of CCINSA \& RISCINSA.5(1): 4-6.

AKTER, S. 2011. Diversity, Morphomerty and Ecological aspects of bats in Jahangirnagar University Campus, Bangladesh. (Unpubl. M.Sc. Thesis)

BATES, P.J.J. and HARRISON, D.L. 1997.Bats of the Indian Subcontinent. Harrison Zoological Museum, Kent, England.xvi+258pp.

CORBET, G.B. and HILL, J.E. 1986. A World List of Mammalian Species. British Museum (Natural History, London. 226pp. 
COX, P.A., ELMQVIST, T., PIERSON, E.D. and RAINEY, W.E. 1991. Flying foxes as strong interactors in South Pacific Island ecosystems: a conservation hypothesis. Conservation Biology.5: 448-454.

FRANCIS, C.M. 2008. A Field Guide to the Mammals of South-east Asia. New Holland Publishers (UK) Ltd, London. 392 pp.

FUJITA, M.S. and TUTTLE, M.D. 1991. Flying foxes (Chiroptera: Pteropodidea) threatened animals of key ecological and economic importance. Conservation Biology.4: 455-463.

HILL, J.E. and SMITH, J.D. 1984. Bats: A Natural History. British Museum (Natural History). 243pp.

HOSSSAIN, A.B.M. E., KHAN, S.A. and ISLAM, M.A. 1995. An inventory of plant diversity in relation with ecology and environment of Jahangirnagar University: I. Vegetational composition and their taxonomic identity. Bangladesh Journal of Life Science.7(1\&2): 95-103.

IUCN Bangladesh. 2000. Red Book of Threatened Mammals of Bangladesh. IUCN Bangladesh Country Officer, Dhaka, Bangladesh, xii+71pp.

KHAN, M.A.R. 2001.Status and distribution of bats in Bangladesh with notes on their ecology. Zoos' Print Journal. 16 (5): 479-483.

KUNZ, T.H. 1988. Ecological and behavioural methods for the study of bats. Washington: Smithsonian Institution Press.

MICKLEBURGH, S.P., HUTSON, A.M. and RACEY, P.A. 2002.A review of the global conservation status ofbats. Oryx. 6 (1): 18-34.

MOHSANIN, S. and KHAN, M.M.H. 2009.Status and seasonal occurrence of the birds in Jahangirnagar University campus, Bangladesh. Bangladesh Journal of Biological Sciences.21(1): 29-37.

RAINEY, W.E., PIERSON, E.D., ELMQVIST, T. and COX, P.A. 1995.The role of flying foxes (Pteropodidae) in oceanic island ecosystem of the Pacific.Pp.47-62, in Ecology, Evolution and Behavior of Bats (Racey PA, Swift SM, eds.). Oxford University Press, London, $421 \mathrm{pp}$.

SAHA, A., HASAN, M.K. and FEEROZ, M.M. 2014. The confirmed record of pouch tomb bat (Saccolaimus saccolaimus) in Bangladesh with notes on morphometry. The Festschrift on the 50th Anniversary of the IUCN Red list of threatened Species ${ }^{T M}$, Dhaka, Bangladesh: IUCN. X+182pp

SARKAR, S.U. and SARKAR, N. J. 2005.Bats of Bangladesh with notes of their status, distribution and habitat. Bat Net-CCINSA Newsletter.6(1): 19-20.

SRINIVASULU, C. and SRINIVASULU, B. 2005.A review of chiropteran diversity of Bangladesh.BAT NET-CCINSA Newsletter. 6 (2): 6-11.

SRINIVASUlU, C., RACEY, P.A. and MISTRY, S. 2010. A key to the bats (Mammalia: Chiroptera) of South Asia. Journal of Threatened Taxa.2 (7): 1001-1076. 
